\title{
Identifying Barriers of Sustainable Construction: A Nigerian Case Study
}

\author{
Ohiomah Ifije $^{1^{*}}$, and Clinton A igbavboa ${ }^{1}$ \\ ${ }^{1}$ Department of Construction Management \& Quantity Surveying, University of Johannesburg, \\ J ohannesburg, 2028, South A frica
}

\begin{abstract}
Sustainable development has become an important part of the lives and aspect of enterprises operations globally. There is a global trend to enhance sustainable practices in all sectors and most especially the construction sectors, this study discusses the factors that best prevent the implementation of sustainable construction in the Nigeria construction industry. The study further explores and determines the reliability of how sustainability should be measured in the Nigeria construction industry. The study used both primary and secondary data to meet the set objective. The primary data were gathered through the use of a questionnaire distributed to construction professionals, contractors and clients. Indicative findings arising from the study revealed that; Building regulations and financial incentives are found to be the main drivers of sustainable construction in Nigeria and Lack of client demand and awareness and a general perception that adopting sustainable construction is expensive. The research concluded by recommending that government help with building policies to help push construction firms towards sustainable construction and also awareness campaigns should be carried out so that clients would demand and be aware of the benefits of sustainable construction
\end{abstract}

Keywords: sustainability, barriers, construction, Nigeria

\section{Introduction}

The construction industry is a very important division for sustainable development because of the impact environmentally and socio-economically. The industry influences in four ways the socio-economic development [1].

The construction industry builds facilities such as roads, buildings and production facility amongst others. Due to a high demand in infrastructural development in developing countries, the contribution of the construction industry to emerging nations is very significant in terms that it supports the economic, social development which turns to wealth, social equality and increases living standard [2]. In developing countries, the construction industry

* Corresponding author: ifije93@gmail.com 
contributes a high percentage to the Gross Domestic Product than the high-income countries $[2,3]$. Examples of this are seen in Brazil whereby the construction industry contributes $14 \%$ to her economy, while in the European Union it contributes 11\% to its GDP [4].

In developing economies which still battle with a high unemployment rate, the construction industry employs a large number of the unemployed because construction is still labour-intensive due to low skills and knowledge due to lack of technology. The end products of construction are spread throughout the country, and it has teamed up to develop private enterprise and technology transfer to all nationals of the nation [5].

Despite all this positive of the construction industry to the economy, the impact of the construction industry cannot be ignored and it is of significant importance, for instance, the construction industry is responsible worldwide for the usage of $40 \%$ of total energy production, $40 \%$ of raw materials and $25 \%$ of timber; the use of $16 \%$ of water, generates 30 $40 \%$ of solid waste and $35-40 \%$ of $\mathrm{CO} 2$ emissions $[6,7,8]$. Hence because of the following impact on the environment, this has led to calls by industry experts on how to lessen the effect of the activities of construction on the environment. This call leads to the concept of sustainable construction which was in line with The Brundtland report [9] on sustainable development which defines sustainable development as the meeting of the wants of the present generation short of compromising the ability of the upcoming generations to meet their wants. Sustainable Construction was defined by Agenda 21 for sustainable construction in Developing Countries (SCDC) as a complete process to restore and maintain agreement amongst the built and natural environments and create settlements that sustain human selfworth and boost economic equity [10]. This description suggests that the early methods, were associated with technical issues, thus do not guarantee a sustainable development while economic and social aspects of sustainability were not well thought-out $[11,12]$. Technical problems of sustainability such as efficient use of resources such as energy and water and the reduction of the environmental effects of materials. Building components and construction technologies are vital parts of sustainable construction. In developing countries, the degree of technical issues of sustainability is very low and most at times underdeveloped. Examples of low and underdeveloped technical issues of sustainability are the aspect of building energy code which does not exist. Therefore, the success of Sustainable Construction (SC) in developing countries is thought-provoking not only because their economic and social conditions may be grim but also because the technical problems are unresolved. The success of SC may necessitate approaches different among developing countries according to the development of their individual construction industries and also their specific socioeconomic condition. For this reason, the overall strategy of Agenda 21 came up with an inclusive strategy for addressing the execution of sustainable construction [10]. Still, there is a conflict at this juncture. On one hand, construction businesses need to be feasible in all areas and, on the other hand, research has shown that the notion that sustainable construction project such as buildings is more expensive than the conventional buildings [13, 14]. Hence because of this notion from literature, this study is seeking to determine the barriers that make it difficult for Nigerian construction firms to implement sustainable construction.

\section{Literature review}

Literature has revealed that the construction industry contributes to the economy if sustainability is pursued in the areas of sustainability of countries as well as Nigeria. As a result, the necessity to implement sustainable construction is imperative as "what we build today will provide the built environment of the future and will influence the ability of future generations to meet their need".

Several countries policies on sustainable development are developed along with global initiatives. Initiatives such as the 1992 Earth Summit (UN Conference on Environmental and 
Development) deliberated on ways of accomplishing sustainable development, setting Agenda 21 as the action plan. Several developed countries have gone on to develop their various national sustainable development strategies. In order for developing to be able to develop their own sustainable development and in turn, sustainable construction strategies [15] suggested a way for attaining sustainable construction, which encompasses all stakeholders such as; government, developers, clients, buyers/end users, contractors, consultants. This route begins with awareness, interest and knowledge of SC. This situation may reduce the drive of construction firms to promote SC practices. In Nigeria, it has been found that no empirical data about what drives' construction businesses in the direction of sustainable construction.

Sustainable construction cannot be discussed without discussing the impact of sustainability on construction.

\subsection{Impact of sustainability}

\subsubsection{Environmental impact}

Creation of waste; developed nations like the UK have come to estimate that $40 \%$ of all UK waste is generated by the construction industry [16]. Due to this waste, the UK government estimate that landfill capacity would stay exceeded by 2017 [17]. In order to combat this issue of landfill, most developed countries have introduced the Landfill Tax and Aggregate Levy which has aided to minimise waste due to the increased costs related to discarding [18]. But this is not the case with developing countries so, at present, construction waste is almost left unattended to.

Energy use; in the UK it has been reported that the built environment consumes roughly $50 \%$ of the aggregate energy generated; $45 \%$ to heat, light and aerate the structures and 5\% to build them. The United Kingdom government is looking to reduce energy by $60 \%$ come 2050 [17]. Even with this policy, the Royal Institute of Charted Surveyors (RICS) is of the belief that the government is not doing enough.

Water use; there has been increased consumption of water in the last $30 \mathrm{yrs}$, this is shown for instance in the UK it has increased to $70 \%$, which will culminate to 4.1 million household's consumption of water by 2016. This is as a result of an increase in populations and living standards which will have an effect on the supply of water. The worldwide construction industry is implementing techniques to conserve water in new build projects. Taking the idea of water efficiency technology such a reduced flow taps, low water flush toilets. This is done with the idea that an estimated $20 \%$ improvement is achieved in proficiency [17].

\subsubsection{Economic impact}

The construction sector contributes meaningfully to the GDP of any nation, the construction industry in the UK contributes about 8\% GDP and over 2 million persons in the UK are hired [5], nearly $20 \%$ of most job created is connected to the sector $[16,19]$ discovered that the key driver to sustainable construction is the client. The debate concerning the impacts on the environment has been clearly demonstrated that the penalties of poorly managed construction instruments can have serious effects on sustainability. In order for this effect to be reduced, the increasing of client awareness must be taken seriously as it is vital in a bid to deviate from mainly financial making decision.

Value management concept has been found to deliver a good economic return, accountability with this positive impact of VM, practitioners of VM have prospects to lessen 
environmental and social change [19]. Construction businesses in order to enhance their standing amongst stakeholders and seek to attract investment [20].

\subsubsection{Social impact}

CIRIA [21] noted that the commercial and residential structures designs, as well as the performance, can affect directly the quality of life, promotion of healthy living and coming together of the community. Everybody connected with a structure can profit from added sustainable practices. Walker [22] acknowledged "Stakeholders can offer tangible value, provide valued response information on how they are affected and can co-operate in delivery of the output". Keeping and shires stated that sustainable buildings benefit from lower.

\subsubsection{Design impact}

The concept of optimum design was better described in the [17] states that optimum design requires optimized performance on the construction site. Studies have shown that design plays a major role in achieving sustainability whereby designers' reputations can be boosted by adding sustainable designs to their building designs. Despite the fact, they have to work off the instruction of the client. The designers have a chance to create an impact in the mind of the client, for instance, capturing the reduced running costs, enhanced corporate image and the occupant's wellbeing better off [23]. Architects play a key role as argued by [24]. Published in 1999 by the Architects Registration Board code of conduct, it was detailed that the responsibility of the architect is to the client, also in consideration to save and improve the quality of the environment as well as the natural resources.

In practice, constructors are not usually tangled in the design and decisions on how sustainable a construction project possibly will be, but good practices here can cut costs and create a green image [25]. This was further backed up by [26] who specified that the choice of construction materials has noticeable and substantial energy and emission of gas implications.

\section{Methodology}

This study adopted a survey method for the gathering of data for this research. The population includes professionals from the built environment within the built environment in the Nigerian construction industry; specifically, in the South-West region.

The study adopted a close-ended questionnaire founded on existing knowledge from literature. The questionnaire was designed to explore the barriers to the implementation of sustainable construction practices. The circulation of questionnaires to respondents was through mainly the google forms sent via email.

The background of the respondents was surveyed in the first section of the questionnaire, while the second portion explored the barriers to sustainable construction implementation amongst the identified construction professionals. A 5-point Likert scale was used to examine based on the level of agreement. The rating was as follows: $1=$ Strongly disagree; $2=$ Disagree; $3=$ Neutral; 4=Agree; 5=Strongly agree. Mean item score (MIS) and standard deviation (SD) were afterwards calculated for each of the variables and the values were used in ranking and determining their position 


\section{Findings}

The table below shows the barriers which impede the implementation of Sustainable Construction in Nigeria.

Table 1. Barriers of Sustainable Construction

\begin{tabular}{|c|c|c|c|}
\hline $\begin{array}{c}\text { Barriers of Sustainable Construction } \\
\text { Lack of customer awareness }\end{array}$ & $\begin{array}{c}\text { Standard } \\
\text { Deviation }\end{array}$ & MIS & Ranking \\
\hline Additional building Costs & 6.00 & 4.00 & 1 \\
\hline $\begin{array}{c}\text { No understanding of the benefits of sustainable } \\
\text { construction }\end{array}$ & 6.70 & 4.00 & 1 \\
\hline Misconception of Construction cost overrun & 5.30 & 3.80 & 3 \\
\hline Lack of coordination cost overrun & 5.20 & 3.70 & 4 \\
\hline Lack of public awareness & 5.60 & 3.70 & 4 \\
\hline Deployment of resources to back technological changes & 5.80 & 3.70 & 4 \\
\hline Initializing sustainability due to lack of building & 3.70 & 3.70 & 4 \\
\hline regulations & & & \\
\hline
\end{tabular}

The table showed the variables and how they are the respondents perceived the barriers, the study hereby revealed that Lack of customer awareness $(\mathrm{SD}=6.00, \mathrm{MIS}=4.00, \mathrm{R}=1)$, in addition, building costs ( $\mathrm{SD}=6.50, \mathrm{MIS}=4.00, \mathrm{R}=1$ ) was ranked the highest as the highest barriers perceived by the professionals sampled, closely followed by No understanding on the benefits of sustainable construction ( $\mathrm{SD}=6.70$, MIS $=3.90$, $\mathrm{R}=2$ ) amongst others were the construction professional's view on the barriers facing the construction industry in Nigeria hindering the implementation of sustainable construction.

These view by professionals' in the Nigerian industry is not only peculiar, but this barrier is also shared by several studies carried out across different countries that found that affordability, lack of customer awareness and demand was the three highest-ranking barriers of sustainable construction in the United Kingdom. It was further corroborated by Zhou and Lowe [27] who pointed out that sustainable construction is expensive, causing a major challenge in the embracing of sustainable construction practices in emerging nations like Nigeria. Furthermore, the finding also corresponds with the study carried out by the Agenda 21 for Sustainable Construction in Developing Countries [10], where it was revealed that the problems of sustainable construction range from deployment of resources to back technological changes.

\section{Conclusions and recommendations}

This research reports the barriers hampering the implementation of sustainable construction practices in the Nigerian construction industry. The information used in this investigation were obtained from both primary and secondary sources. The secondary data which is literature show that the construction sector is an important contributor to the pollution worldwide which have an effect on the ecosystem in numerous ways. On the other hand, 
the focal test for the sector is to play an important part in the reduction of the impacts of construction happenings on the environment. Collected works also exposed that the construction industry will play an important role in achieving the society's sustainable goals but the way to achieve sustainability is a process which is proving difficult.

Results from the empirical survey showed there is a discrepancy of views on achievement practices of sustainable construction implementation in the sector such as Lack of customer awareness being the highest rank, followed by the additional building cost ranked as next to the implementation of sustainable construction. Similarly, the professionals additionally saw sustainable construction activities as an additional cost to the ever-increasing ways of construction practices in terms of purchasing new machinery and training of staff which is true as this thought could lead to not implementing SC.

It is of importance that construction professionals in the Nigerian construction industry must seek to overcome the barriers that hinder the implementation of sustainable construction. As the long-term benefits from the implementation outweigh the present practices. it is of importance that awareness of sustainable construction must be carried out amongst the professionals, clients as this will help in the drive for the implementation of SC. Lastly; it is the responsibility of construction professionals involved with sustainable construction processes to enlighten the clients on the benefits of SC.

This study has shown that there has to be an increase in awareness for the embracing of sustainable construction practices, hence it is recommended that government and nongovernment agencies must help in the increase of the awareness of sustainable construction practices. Henceforth, it is also suggested that more enforced approaches and actions must be pursued aggressively to hasten up the method in forming a sustainable-driven construction industry, which is principal to building a sustainable future.

\section{References}

1. G. Ofori, Construction in developing countries, Construction Management and Economics, 25, 1-6 (2007)

2. V. Gomes, M.G.D. Silva, Exploring sustainable construction: implications from Latin America, Building Research \& Information, 33, 428-440 (2005)

3. V.M. John, V. Agopyan, C. Sjostrom, An agenda 21 for Latin American and Caribbean construbusiness. A perspective from Brazil. [online], Available: http://www.cbcs.org.br/userfiles/bancoD eC onhecimento/A genda $\% 2021 \% 20$ for $\% 2$ OL atin\%20A merican\%20C onstrubusiness.pdf (2001)

4. V.M. John, Recycling of wastes in construction: a contribution to the methodology for research and development, Escola Politécnica, USp (2000)

5. D.A. Turin, The construction industry: its economic significance and its role in development. Building economic research unit, University College of London (1973)

6. H. Son, C. K im, W.K. Chong, J.-S. Chou, Implementing sustainable development in the construction industry: constructors' perspective in the US and Korea, Sustainable Development 19(5), 337-347 (2011)

7. E. Van Bueren, J. De Jong, Establishing sustainability: policy successes and failures, Building Research\& Information, 35, 543-556 (2007)

8. U. Berardi, Clarifying the new interpretations of the concept of sustainable buildings, Sustainable Cities and Society, 8, 72-78 (2013)

9. Our common future, WCED, World Commission on Environment and Development, UK, Oxford U niversity Press (1987)

10. C. Du Plessis, Agenda 21 for sustainable construction in developing countries, CSIR report B oU/e0204, CSIr, UN ep-letC, and Pretoria (2002) 
11. C. Du Plessis, A strategic framework for sustainable construction in developing countries, Construction M anagement and E conomics, 25, 67-76 (2007)

12. F. Shafii, Z.A. Ali, M.Z. Othman, Achieving sustainable construction in the developing countries of Southeast Asia, in 6th A sia-Pacific Structural Engineering and Construction Conference, K uala-L umpur, M alaysia (2006)

13. J. Y udelson, Green building through integrated design, M CGraw-Hill Companies, Inc, New Y ork

14. I.B. Robichaud, V.S. A nantatmula, Greening project management practices for sustainable construction, J ournal of M anagement in Engineering, 27, 48-57 (2011)

15. N. Zainul-Abidin, Investigating the awareness and application of sustainable construction concept by Malaysian developers, Habitat International 34, 421-426 (2010)

16. Sustainable Construction (Worldwide), Royal Institute for Chartered Surveyors, Coventry, available at: http://www .rics.org RICS (2005)

17. Better Buildings Summit Issues Paper, Department of Trade and Industry, HM SO, London, available at: www.dti.gov.uk/construction/sustain/betbuild.pdf, Better Buildings Summit (2003)

18. The Organisation of Economic Co-operation and Development Environmental Performance Review - UK's Progress Report, Department for Environment, Food and Rural Affairs, Organisation of Economic Cooperation and Development, Paris, available at: www.defra.gov.uk/environment/internat/oecd/pdf/epr-ukreport OECD (2006)

19. N.S. A bidin, C.L. Pasquire, Delivering sustainability through value management: concept and performance overview, Engineering, Construction and A rchitectural M anagement, 12, 168-80 (2005)

20. Making the most of Our Built Environment, Sustainability Construction Task Group, 2004, available at: www.dti.gov.uk/construction/sustain/making_the_most.pdf (accessed $22 \mathrm{M}$ arch 2006)

21. Compliance Sustainability, Construction Industry Research and Information, Council, London, available at: www.ciria.org/complianceplus/sustainability.htm CIRIA, (2006)

22. D.H.T. Walker, Client/customer or stakeholder focus? ISO 14000 EMS as a construction industry case study, The TQM M agazine, 12, 18-25 (2000)

23. A. Y ates, Sustainable buildings: benefits for constructors, Building Research Establishment (2003a)

24. D.P. Wyatt, A. Sobotka, M. Rogalska, Towards a sustainable practice, Facilities, 18, 76-82 (2000)

25. Y ates, BRE IP13/03 Part 2 Sustainable Buildings: Benefits for Designers, BRE Centre for Sustainable Construction, W atford (2003b)

26. G. Treloar, R. Fay, B. Ilozor, P.E.D L ove, Building materials selection; greenhouse strategies for built facilities, Facilities, 19, 139-49 (2001)

27. L. Zhou, D.J. Lowe, Economic challenges of sustainable construction, in Proceedings of RICS COBRA Foundation Construction and Building Research Conference, 1-2 (2003) 